\title{
A new approach for mapping forest management areas in Canada
}

by Graham Stinson ${ }^{2 *}$, Gurp Thandi ${ }^{1}$, Darren Aitkin², Chris Bailey ${ }^{3}$, James Boyd ${ }^{4}$, Michelle Colley ${ }^{5}$, Catherine Fraser ${ }^{3}$, Lane Gelhorn ${ }^{6}$, Kathleen Groenewegen ${ }^{7}$, Adam Hogg ${ }^{5}$, Joe Kapron ${ }^{8}$, Antoine Leboeuf ${ }^{9}$, Matt Makar ${ }^{10}$, Mike Montigny ${ }^{11}$, Boyd Pittman ${ }^{12}$, Kirk Price ${ }^{13}$, Tim Salkeld ${ }^{14}$, Lisa Smith ${ }^{7}$, Antonio Viveiros ${ }^{4}$ and Dale Wilson ${ }^{15}$

\begin{abstract}
Canada's forests have frequently been characterized using binary classifications such as intact/non-intact or managed/unmanaged. A more nuanced classification approach is needed to better understand the geography of forest management in Canada. The best way to represent Canada's complex diversity of forest management regimes with a simple classification is to categorize according to ownership, protection status and tenure. We gathered federal, provincial and territorial geospatial datasets and used a binary decision tree approach in GIS to classify land into nine classes: (i) Protected, (ii) Restricted, (iii) Federal Reserve, (iv) Indian Reserve, (v) Treaty/Settlement, (vi) Private, (vii) Long-Term Tenure, (viii) Short-Term Tenure, and (ix) Other. These classes are broad; management intensity may vary considerably within classes. Not all forests in Long-Term Tenure or Short-Term Tenure areas are available for timber supply. Government regulations establish considerable reserve areas within forest management units where harvesting is not permitted. The resulting map dataset is current to 2017 and will need to be updated as land designations change.
\end{abstract}

Key words: forest management; managed forest; forest map; forest classification; Canada; forest tenure

\section{RÉSUMÉ}

Les forêts du Canada ont souvent été décrites au moyen d'une classification binaire comme intacte/non intacte ou aménagée/non aménagée. Une nouvelle approche plus nuancée est requise afin de mieux comprendre la géographie de l'aménagement forestier au Canada. La meilleure façon de représenter la diversité complexe des modes d'aménagement forestier du Canada par une simple classification est de la décrire en fonction du type de propriété, du statut de protection et de la tenure. Nous avons réuni les ensembles de données géospatiales fédérales, provinciales et territoriales pour les soumettre à un schéma de décision binaire sous forme de SIG afin de représenter le territoire selon neuf classes : (i) protégé, (ii) limité, (iii) réserve fédérale, (iv) territoire autochtone, (v) territoire concédé, (vi) privé, (vii) tenure à long terme, (viii) tenure à court terme et (ix) autre. Ces classes sont générales; l'intensité de l'aménagement peut varier considérablement au sein de ces classes. Ce ne sont pas toutes les forêts des classes de tenure à long terme ou de tenure à court terme qui sont disponibles à des fins d'approvisionnement en matière ligneuse. Les réglementations gouvernementales ont créé un grand nombre de réserves au sein des unités d'aménagements forestiers où la récolte n'est pas permise. La carte obtenue à partir de ces données est valide en date de 2017 et devra être mise à jour selon les modifications apportées à la désignation du territoire.

Mots clés : aménagement forestier ; forêt aménagée ; carte forestière ; classification forestière ; Canada ; tenure forestière

\footnotetext{
${ }^{1}$ Natural Resources Canada, Canadian Forest Service, Pacific Forestry Centre, 506 W Burnside Rd, Victoria, BC V8Z 1M5 Canada *corresponding author email: graham.stinson@canada.ca

${ }^{2}$ Alberta Agriculture and Forestry, Forest Resource Analysis Section, 9920108 Street NW, Edmonton, AB T5K 2M4 Canada

${ }^{3}$ Nova Scotia Department of Lands and Forestry, 15 Arlington Place, Truro, NS B2N 0G9 Canada

${ }^{4}$ Manitoba Sustainable Development, Forestry and Peatlands, 200 Saulteaux Crescent, Winnipeg, MB R3J 3W3 Canada

${ }^{5}$ Ontario Ministry of Natural Resources and Forestry, 300 Water Street, Peterborough, ON K9J 8M5 Canada

${ }^{6}$ Saskatchewan Ministry of Environment, Forest Service, PO Box 3003, Prince Albert, SK S6V 6G1 Canada

${ }^{7}$ Northwest Territories Department of Environment and Natural Resources, Forest Management Division, Lot 173, Hay River Reserve, Hay River, NT X0E 1G3 Canada

${ }^{8}$ Ontario Ministry of Natural Resources and Forestry (retired)

${ }^{9}$ Québec Ministère des Forêts, de la Faune et des Parcs, Direction des Inventaires Forestiers, 5700 4ième Avenue Ouest, Québec, QC G1H 6R1 Canada

${ }^{10}$ British Columbia Ministry of Forests, Lands, Natural Resource Operations, and Rural Development, Forest Analysis and Inventory Branch, 441 Columbia Street, Kamloops, BC V2C 2T3 Canada

${ }^{11}$ Prince Edward Island Department of Communities, Land \& Environment, Forests, Fish and Wildlife Division, 183 Upton Road, Charlottetown, PE C1A 7N8 Canada

${ }^{12}$ Newfoundland \& Labrador Department of Fisheries and Land Resources, Forest Ecosystem Management Division, 192 Wheelers Road, Corner Brook, NL A2H 6J8 Canada

${ }^{13}$ Yukon Energy, Mines and Resources, Forest Management Branch, Mile 918 Alaska Hwy, Whitehorse, YT Y1A 2C6 Canada

${ }^{14}$ British Columbia Ministry of Forests, Lands, Natural Resource Operations and Rural Development, Forest Analysis and Inventory Branch, PO Box 9512, Stn Prov Govt, Victoria, BC V8W 9C2 Canada

${ }^{15}$ New Brunswick Department of Energy and Resource Development, Forest Planning and Stewardship Branch, 774 James Kidd Flemming Circle, Fredericton, NB E3C 2G6 Canada
} 


\section{Introduction}

Canadian forest industry employed 209940 people in 2017 and contributed $\$ 24.6$ billion to Canada's gross domestic product (NRCan 2018) but many Canadian forests have no forest sector activity. Potapov et al. (2017) mapped Intact Forest Landscapes (IFL) globally and found that Canada has more IFL than any other country. Forests unaltered by human activity are considered to be more effective at preserving ecosystem services and biodiversity when compared with altered forests (Venier et al. 2018; Watson et al. 2018). Binary categorizations of Canada's forests into intact/non-intact, managed/unmanaged, or production/protection areas can be informative, but they do not provide enough information to understand the degree of alteration. They tend to characterize all managed/non-intact/production landscapes as being equal in terms of their effectiveness at preserving ecosystem services and biodiversity or lack thereof. Such simplifications could lead to the development of policies that fail to encourage sustainable forest management.

Apsey et al. (2000) characterized Canadian forest management history as a sequence of eras beginning with a Liquidation Era during European settlement and evolving through a Conservation Era to a Sustained Yield Era. We now find ourselves in an era of Sustainable Forest Management (SFM). SFM is an attempt to develop a better balance between economic, environmental and social values. SFM is an adaptive journey, not a destination. It involves managing the forest, recognizing and sustaining multiple values to achieve multiple objectives. The objectives and the methods employed to achieve them are continuously assessed and refined. The Canadian Council of Forest Ministers (CCFM) developed a set of criteria and indicators (C\&I) to measure SFM progress (CCFM 2007), and a similar set of C\&I are used by Montreal Process member countries, including Canada, to measure SFM progress throughout the world's temperate and boreal forests (Montreal Process 2015). Provincial and territorial governments in Canada have incorporated SFM principles into their forestry-related legislation and policies. Canadian forest industry has also embraced the SFM paradigm. There is presently more forest area with third-party forest management certification in Canada than in any other country (NRCan 2017). Governments, companies, Indigenous Peoples, communities and stakeholders are all engaged in the forest management planning process. Management objectives and the plans developed by professional foresters to achieve those objectives differ from place to place. Public forests are generally managed differently from privately owned forests because they have different governance and there are different interests involved. In public forests, each jurisdiction has its own system of governance, its own laws, its own regulations and often its own predominant school of forestry.

An understanding of forest ownership and tenure is needed to understand forest management in Canada. Ninety percent of our forests are on provincial or territorial Crown land (NRCan 2018). Timber supply comes from both Crown (85\%) and privately owned (15\%) forests (NFD 2019), but most wood processing capacity is privately owned. Provincial and territorial governments use a variety of tenure arrangements to grant access to Crown timber (see Supplementary Materials, Table S1). Some tenure arrangements grant access to a specified volume of timber while others grant access to timber resources in a specified area. Tenures may overlap or only apply to certain types of timber within a designated area, resulting in a complex mosaic of tenure arrangements across Canada's forests. Even within forest management units with tenure arrangements, many areas are set aside to achieve non-timber management objectives in accordance with government regulations or industry's own ecosystem-based management objectives. Some of these areas are delineated on maps while others are specified in relation to non-permanent features on the ground. Government regulations place restrictions, for example, on harvesting activities within specified distances of riparian features and certain wildlife habitat features without mapping all of these; instead, forest planners must flag the required areas as they are encountered during operations.

A map showing private lands and Crown forest tenure areas would provide a good starting point for understanding the general extent of commercial forestry in Canada. Provincial and territorial governments frequently provide this type of geospatial information. Such information is commonly made openly available following jurisdiction-specific open government principles. However, these maps are seldom available in a common or standardized format, so pan-Canadian map products are rarely available.

The lack of pan-Canadian map data availability has occasionally been addressed by non-government organizations. Global Forest Watch (GFW) maintains a collection of provincial tenure area map datasets titled "Canada forest tenures" that is publicly accessible online (data.globalforestwatch.org). The GFW data portal notes that their compiled layer may not be comprehensive of all existing concessions (tenure areas) and the location of certain concessions may be inaccurate.

The Forest Products Association of Canada (FPAC) maintains an online map of areas having forest management certification (certificationcanada.org). Many firms in Canada use third party certification, such as Forest Stewardship Council (FSC), Sustainable Forestry Initiative (SFI) or Canadian Standards Association (CSA), to assure consumers that their practices are being carried out in a way that meets accepted environmental, social and economic criteria for responsible forestry.

Forest management activities are occasionally undertaken on Federal Crown lands such as military bases and training areas. Management activities, such as prescribed burning to maintain fire-dependent ecosystems and reduce the risk of extreme fires, are undertaken in many parks and protected areas. Restricted harvesting is also permitted in some parks. Many of southern Manitoba's provincial parks, for example, were originally established as timber reserves to protect forest resources from over-exploitation by Prairie settlers. Forest management activities are also undertaken on some Indian Reserves and Treaty and Settlement Lands. A map showing all of these areas, in addition to private lands and Crown forest tenure areas, is needed to better understand where forests are being managed, by whom and for what objectives.

\section{Methods}

\section{Forest Management Categorization}

Forests are managed using a variety of practices tailored to local circumstances to achieve sustainable forest management objectives. There are, nevertheless, some commonali- 


\begin{tabular}{lll}
\hline Code & Name & Description \\
\hline 0 & Not Available & Lands with no classification \\
11 & Long-term Tenure & Lands with long-term volume- or area-based Crown timber dispositions \\
12 & Short-term Tenure & Lands with short-term volume- or area-based Crown timber dispositions \\
13 & Other & Lands with no Crown timber dispositions \\
20 & Protected & Lands with legal protection status (IUCN class Ia, Ib, II, III, IV, V or VI equivalent) \\
31 & Federal Reserve & Lands held in reserve by the federal government for military or other purposes \\
32 & Indian Reserve & Lands held in reserve by the federal government under the Indian Act \\
33 & Restricted & Lands reserved or designated restricted use by provincial or territorial government \\
40 & Treaty/Settlement & Treaty Settlement Lands, Settlement Lands, Metis Settlements, Inuit-owned lands and Labrador Inuit Lands \\
50 & Private & Privately-owned lands \\
100 & Water & Lakes and rivers \\
\hline
\end{tabular}

ties to use as a basis for nationally standardized categorization. We determined that the best way to categorize would be according to ownership, protection status and tenure because these can be related to forest management interests, governance and objectives in a generalized way across all Canadian jurisdictions.

Table 1 shows the classes we developed and Fig. 1 shows the decision tree used to assign units of land to these classes. The classes were numbered to provide some functional grouping such as MF_codes 11,12 and 13 which all correspond to provincial and territorial land with different tenures. The label "MF_code" arose during dataset creation as a shorthand for "managed forest type code".

Protected (MF_code 20) lands were identified using the Canadian Council on Ecological Areas' (CCEA) Conservation Area Reporting and Tracking System (CARTS) geodatabase (CCEA 2016) to map all International Union for Conservation of Nature (IUCN) category I through VI protected areas in Canada (CCEA 2008). Algonquin Provincial Park in Ontario was treated as a special case because restricted forest management activities are permitted in portions of the park. Duck Mountain Provincial Park in Manitoba was also treated as a special case because it continues to serve its original purpose as a provincial timber reserve. Algonquin and portions of Duck Mountain were not classified as Protected. The 2016 CARTS geodatabase was used because it was the most current version available at the time.

Treaty/Settlement (MF_code 40) lands were identified using the Geobase Aboriginal Lands of Canada geodatabase (NRCan 2016) in addition to jurisdiction specific data sources in B.C., Alberta and Labrador. These lands are owned (fee simple) by a First Nation, Metis or Inuit authority who also exercises certain law-making powers and surface rights. Terminology varies from nation to nation. In some cases, these lands are referred to as treaty settlement lands; in others, they are referred to as settlement lands. In addition to their rights on these lands, First Nation, Metis and Inuit authorities generally also have certain non-exclusive rights in a broader area defined in treaties, settlements or final agreements with the Crown. These broader areas were not classified as Treaty/Settlement and we did not map them. Treaty/Settlement lands are quite distinct from Indian Reserves.

Indian Reserve (MF_code 32) lands were identified using the Geobase Aboriginal Lands of Canada geodatabase
(NRCan 2016). The Indian Act (R.S.C. 1985, c. I-5) defines these as Crown lands that have been "set apart by Her Majesty for the use and benefit of a band".

Federal Reserve (MF_code 31) lands were identified using all Directory of Federal Real Property polygons greater than 10 ha in size not classified as "parks and recreation" (Government of Canada 2016). Additional military lands and Federal reserves that we identified using provincial data sources were also classified as Federal Reserve.

Restricted (MF_code 33) lands were identified using provincial and territorial datasets. In B.C., these include Crown ecological reserves, biodiversity areas, mining areas, tourism areas, public recreation areas, Class A provincial parks and provincial park equivalent areas. In Alberta, this includes areas identified as interim protected areas and forest management units with restricted activities. In Saskatchewan, this includes special management areas in the Taiga Shield. In Manitoba, this includes ecological reserves, park reserves, wildlife management areas and traditional use planning areas not already identified as Treaty/Settlement land. In Ontario, Quebec and Nova Scotia, this includes lands held by provincial government agencies for particular nonforestry land uses plus provincial park and reserve areas not already classified as Protected.

Private (MF_code 50) lands were identified using provincial and territorial land ownership datasets. Detailed ownership datasets were not available in all jurisdictions and so proxies were used where necessary. In Saskatchewan, lands south of the province's Commercial Forest Zone were classified as Private. This included some Crown lands but these are generally small and not included in forest management plans or leased for commercial forestry purposes.

All Crown lands not already classified into the above categories were coded as Long-Term Tenure, Short-Term Tenure or Other based on commercial tenure. Long-Term Tenure (MF_code 11) includes lands having long-term volume- or area-based tenure or effectively having the equivalent (i.e., consistently recurrent commercial forest tenure with associated forest management activity). Short-Term Tenure (MF_code 12) includes lands having shorter-term volume- or area-based tenure (5 years or less). Table 2 lists all lands that were classified as Long-Term Tenure and ShortTerm Tenure in each province and territory. Lands were classified as Long-Term Tenure (MF_code 11) where both longand short-term tenures are present. 


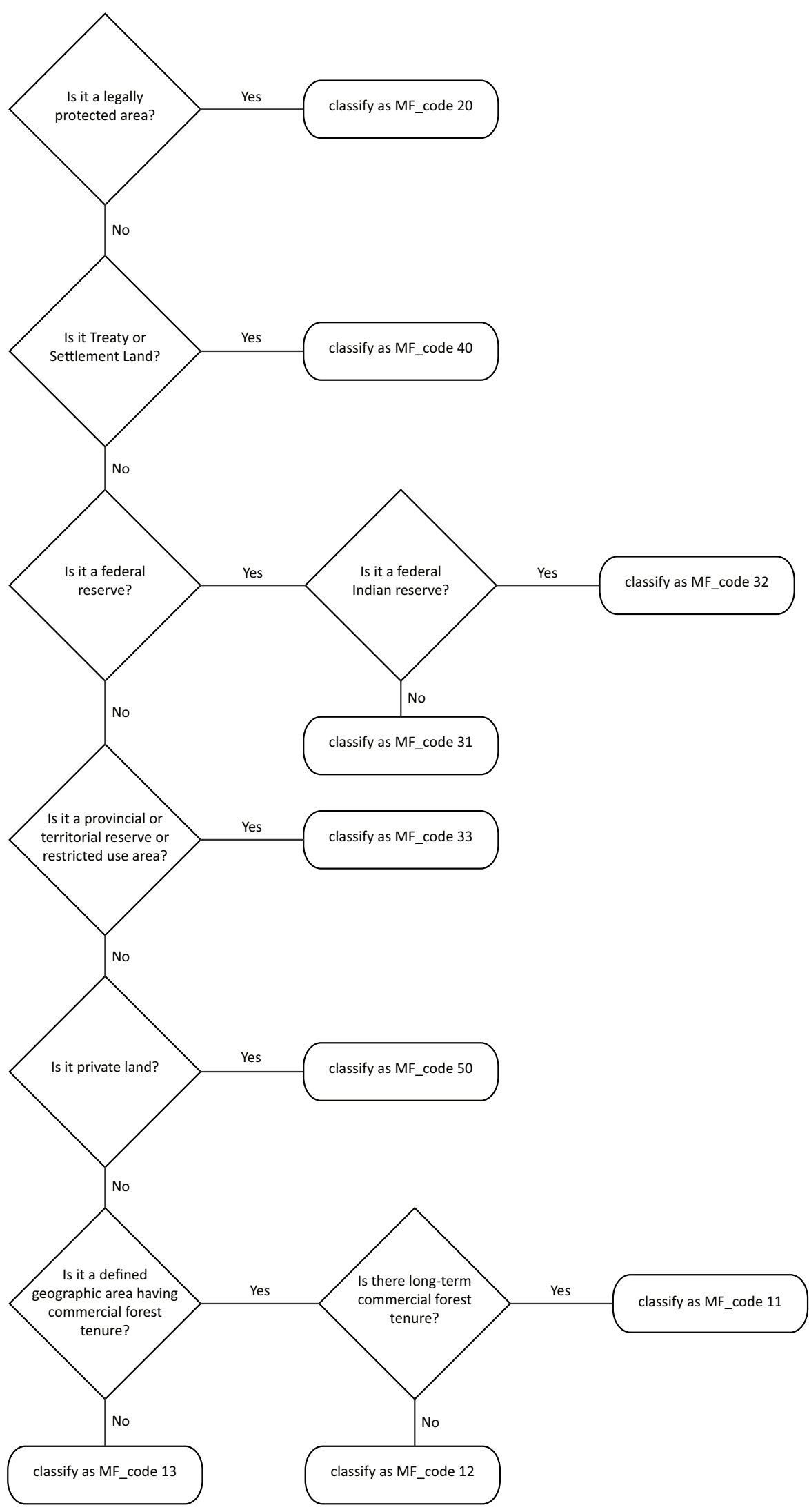

Fig. 1. Land Classification Decision Tree. Detailed information on data sources used and exceptions made is provided in Supplementary Materials. After all classification steps depicted in this decision tree were completed, a final step was applied where water areas llakes and rivers) were added, overruling land classifications for areas covered by water 
Table 2. Crown tenure classification assignments. Details are provided in Supplementary Materials

\begin{tabular}{|c|c|c|}
\hline & Long-Term Tenure & Short-Term Tenure \\
\hline British Columbia & $\begin{array}{l}\text { Crown active timber licences in a Timber Supply } \\
\text { Area (TSA) or Tree Farm Licence (TFL) and private } \\
\text { Schedule A and B lands }\end{array}$ & $\begin{array}{l}\text { Crown and private woodlot licence and } \\
\text { community forest lands }\end{array}$ \\
\hline Alberta & $\begin{array}{l}\text { Forest Management Agreement (FMA) areas and } \\
\text { Forest Management Units (FMU) with Timber } \\
\text { Quotas }\end{array}$ & Forest Management Units (FMU) with Permits \\
\hline Saskatchewan & $\begin{array}{l}\text { Forest Management Agreement (FMA) areas and } \\
\text { FMA-like long-term Timber Supply Licence (TSL) } \\
\text { areas (Meadow Lake OSB TSL and North West TSL) }\end{array}$ & $\begin{array}{l}\text { Commercial forest management units (FMU) } \\
\text { excluding FMA areas and FMA-like TSL areas }\end{array}$ \\
\hline Manitoba & $\begin{array}{l}\text { Forest Management Licence Agreement (FMLA) } \\
\text { areas }\end{array}$ & $\begin{array}{l}\text { Provincial Crown lands classified as Open that } \\
\text { are outside of FMLA areas }\end{array}$ \\
\hline Ontario & $\begin{array}{l}\text { All Forest Management Units (FMU) except } \\
\text { Algonquin }\end{array}$ & Algonquin FMU \\
\hline Quebec & All Crown land with privately held forest tenure & $\begin{array}{l}\text { Other Crown lands accessible for restricted forest } \\
\text { resource management }\end{array}$ \\
\hline New Brunswick & All licenced provincial Crown land & None \\
\hline Prince Edward Island & None & None \\
\hline Nova Scotia & Forest Utilization License Agreement (FULA) areas & $\begin{array}{l}\text { Any other crown land covered by an agreement } \\
\text { other than FULA regarding utilization (short- } \\
\text { term timber licenses, working community forests } \\
\text { and pilot projects or other agreements) }\end{array}$ \\
\hline Newfoundland \& Labrador & All long-term and recurrent commercial tenure areas & None \\
\hline Northwest Territories & $\begin{array}{l}\text { Legislated Forest Management Units with } 25 \text {-year } \\
\text { Forest Management Agreements (FMA) }\end{array}$ & None \\
\hline Yukon & $\begin{array}{l}\text { Dawson, Teslin and Champagne and Aishihik forest } \\
\text { management planning areas }\end{array}$ & $\begin{array}{l}\text { Timber harvest planning areas outside of the } \\
3 \text { forest management planning areas }\end{array}$ \\
\hline Nunavut & None & None \\
\hline
\end{tabular}

All remaining lands were classified as Other (MF_code 13). Forests in these areas are not entirely free of human activity. Fire suppression often occurs and there may be local use of forest resources but not at a large scale. Human activities unrelated to forestry can also occur in these forests (e.g., mining, hydro-electric reservoirs, and electricity transmission).

Lastly, Statistics Canada's lakes and rivers polygon file (Statistics Canada 2011) was used to identify lakes and rivers not already identified in the datasets used to classify land areas in the steps described above. Lakes and rivers were given MF_code 100 (Water).

\section{GIS data processing}

Data from each province and territory were first processed separately. The source datasets were too large to be processed all at once. Datasets were overlain to produce a resultant dataset implementing all of the classification steps above except for the last one (water). The resultant dataset was then transformed from vector format to $250 \mathrm{~m}$ by $250 \mathrm{~m}$ raster (6.25 ha tiles) to resolve spatial discrepancies such as borders mapped by different source datasets using different mapping scales, which create issues such as overlaps and gaps in the resultant dataset. During the vector-to-raster transformation process, the area of each tile coded to each MF_code was calculated and, in each tile, the predominant class by area was assigned to the entire tile. A large number of sliver features were created by the geographic intersection of roads and rivers that were mapped as polygons differently in source datasets. We found, for example, rivers that were coded to one MF_code along some segments, to another MF_code along other segments, and not mapped at all along other segments. We wanted to eliminate as many of these inconsistently represented features as possible. The vector-to-raster generalization process eliminated most geographic misalignment issues and most sliver features.

The provincial and territorial rasters were then joined together and projected using Canada Albers Equal Area Conic, an area-preserving map projection. The national raster was then transformed back into vector format for manual cleaning, which involved fixing the remaining gaps 


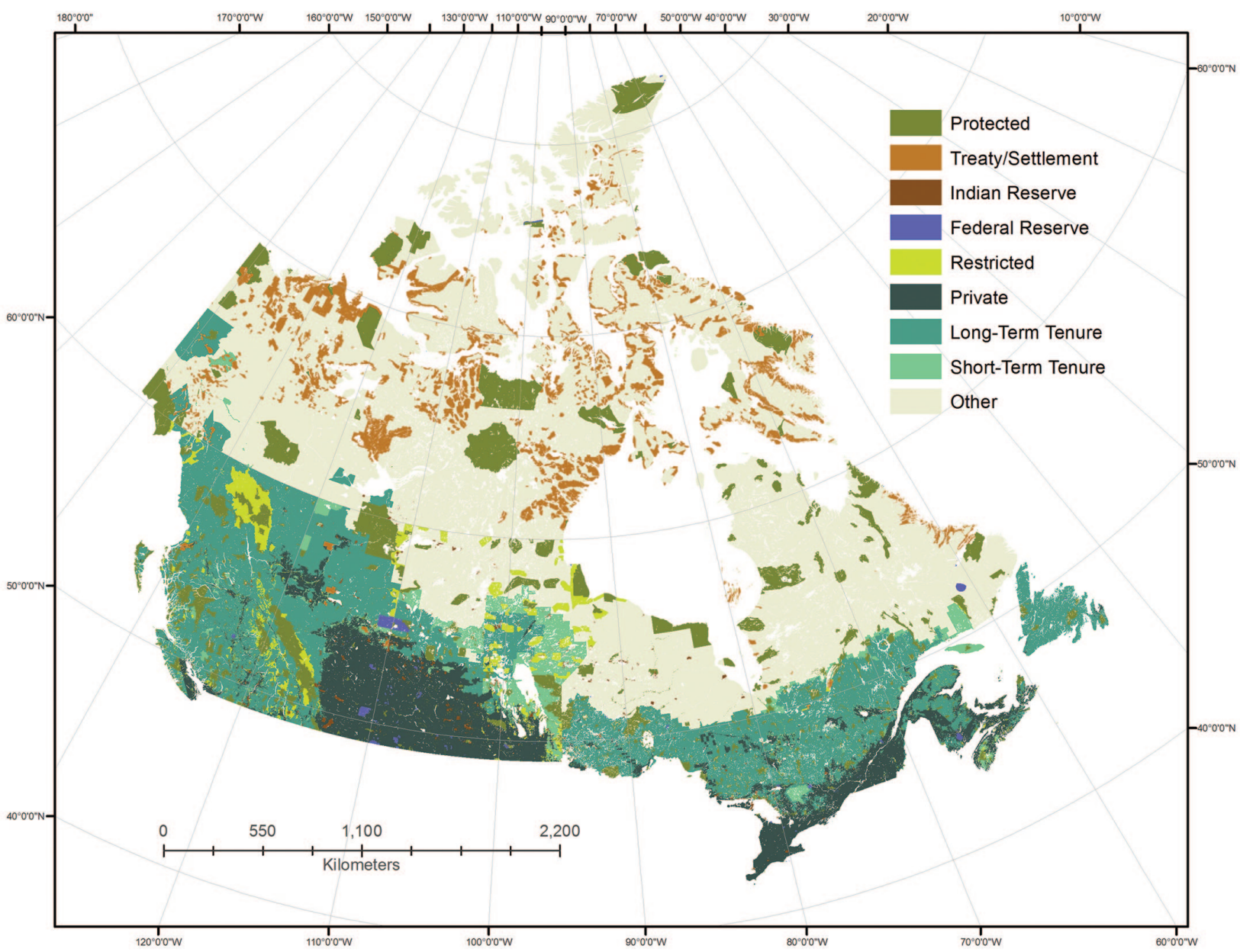

Fig. 2. National map dataset resulting from classification process shown in Fig. 1, applied to all lands in Canada irrespective of whether they are forest or not

between datasets and eliminating the remaining inconsistently represented features that were not eliminated by the raster transformation steps. Once this step was completed, we then overlaid the water layer to classify lakes and rivers. This step was performed last because we did not want to generalize these features. We had no need to because they were already packaged as a nationally consistent dataset with no gaps or overlaps.

The resulting dataset is shown in Fig. 2. This dataset provides a classification for all lands in Canada irrespective of whether they are forested or not. A detailed description of source datasets and processing steps is provided in the Supplementary Materials.

\section{Map production and quantitative assessment methods}

The final geospatial dataset, Canada_FM, provides a spatially exhaustive classification of lands in Canada. It does not differentiate areas of forest from non-forest. The calculation of forest area in each class had to be conducted using the
Canada_FM dataset in combination with forest inventory data. The Food and Agriculture Organization (FAO) of the United Nations defines forest as "land spanning more than 0.5 hectares with trees higher than $5 \mathrm{~m}$ and a canopy cover of more than $10 \%$ or trees able to reach these thresholds in situ. It does not include land that is predominantly under agricultural or urban land use" (FAO 2012). According to this definition, treed land can be non-forest and non-treed land can be forest. A recently harvested cutblock is forest even though it currently has no trees for example, just as a recently harvested agricultural crop field is cropland, even though it currently has no crop. Treed areas that are predominantly under agricultural or urban land use are not forest. Area of forest, therefore, is not the same as area of tree cover. Consequently, area of forest is not easily mapped using satellite imagery.

Despite these issues, we elected to make a national map using tree cover as a proxy for forest for pragmatic reasons. A binary treed/non-treed mask was produced using two datasets produced by Beaudoin et al. (2014) from National 


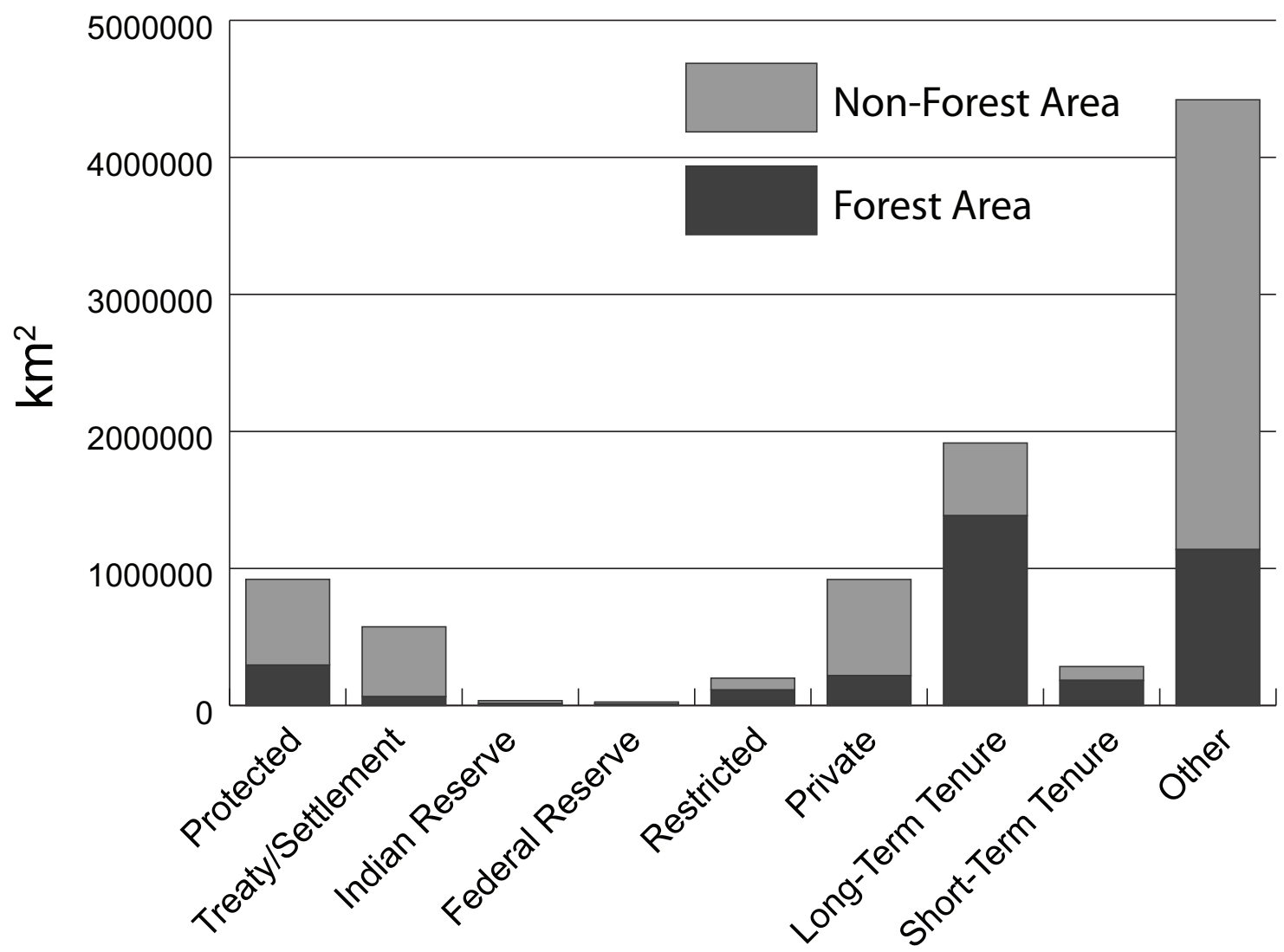

Fig. 3. Area of forest and non-forest land in each forest management area land category

Forest Inventory (NFI) baseline data using the k-nearest neighbour's imputation technique $(\mathrm{kNN})$. The $\mathrm{kNN}$ forest height dataset was combined with the $\mathrm{kNN}$ canopy closure dataset to create a new $250 \mathrm{~m}$ by $250 \mathrm{~m}$ raster dataset with all pixels having canopy cover $25 \%$ or greater and tree heights 5 m or greater classified as forest. A $25 \%$ canopy closure threshold was used instead of the $10 \%$ threshold provided by FAO because the $10 \%$ threshold produced a mask that had too much land area classified as forest in the high latitudes. This weakness was caused by the fact that NFI baseline data in those areas were derived from moderate resolution land cover data (Wulder et al. 2008) rather than interpreted stereo photo imagery (Gillis and Leckie 1993). The treed/non-treed raster mask was created for cartographic purposes only, not for use in quantitative analyses. We did not quantitatively analyze the area included in the mask using $10 \%$ or $25 \%$ canopy cover thresholds because the mask was not used to perform any calculations, and we encourage others to avoid doing so as well. This raster mask, in combination with the Canada_FM dataset, is useful for portraying forest distribution and the geography of forest management across Canada. For quantitative analyses of forest areas, a geographic intersection of Canada_FM with the NFI baseline photo plot data was performed and then the NFI standard statistical procedures were used to calculate estimates (NFI 2004; Stinson et al. 2016).

\section{Results}

Twenty percent of Canada's land area was classified as LongTerm Tenure and three percent as Short-Term Tenure (Fig. 2). Both classes are forest-dominated. Land with LongTerm Tenure is $72 \%$ forested and land with Short-Term Tenure is $64 \%$ forested (Fig. 3). Forty percent (139 million ha) of Canada's forest (by area) is in Long-Term Tenure areas and 5\% (18 million ha) is in Short-Term Tenure areas (Table 3). Just over half of the total volume is in Long-Term or Short-Term Tenure areas.

Ten percent of Canada's land area is Private (Fig. 2), but the majority of these lands are non-forested (Fig. 3). Only 6\% of Canada's forest (22 million ha) is Private, consistent with NFI ownership data (Table S4). Fig. 4 shows that the majority of Private forest is located in the Maritime Provinces and in southern Quebec and Ontario.

Ten percent of the land area is classified as Protected (Fig. 2). These areas are $32 \%$ forested (Fig. 3). About $8.5 \%$ of Canada's forest ( 30 million ha) is in Protected areas. This is 
Table 3. Forest area and growing stock estimated using National Forest Inventory baseline data

\begin{tabular}{|c|c|c|c|c|c|}
\hline & $\begin{array}{c}\text { Area } \\
\text { (thousand ha) }\end{array}$ & $\begin{array}{l}\text { Percent of national } \\
\text { total forest area }\end{array}$ & $\begin{array}{l}\text { Total volume } \\
\left(\text { million } \mathbf{m}^{3}\right)\end{array}$ & $\begin{array}{l}\text { Percent of national } \\
\text { total volume }\end{array}$ & $\mathrm{m}^{3} / \mathrm{ha}$ \\
\hline Long-term Tenure & 138519 & 39.9 & 21911 & 46.4 & 158.2 \\
\hline Short-term Tenure & 18330 & 5.3 & 2206 & 4.7 & 120.3 \\
\hline Protected & 29508 & 8.5 & 5133 & 10.9 & 174.0 \\
\hline Federal Reserve & 1087 & 0.3 & 225 & 0.5 & 207.2 \\
\hline Indian Reserve & 1528 & 0.4 & 245 & 0.5 & 160.4 \\
\hline Restricted & 11333 & 3.3 & 1658 & 3.5 & 146.3 \\
\hline Treaty/Settlement & 6443 & 1.9 & 839 & 1.8 & 130.2 \\
\hline Private & 21857 & 6.3 & 3345 & 7.1 & 153.0 \\
\hline Other & 113807 & 32.7 & 11092 & 23.5 & 97.5 \\
\hline Water & 4558 & 1.3 & 496 & 1.0 & 108.8 \\
\hline Not Available & 533 & 0.2 & 92 & 0.2 & 173.4 \\
\hline Total & 347503 & 100.0 & 47243 & 100.0 & 135.9 \\
\hline
\end{tabular}

* Total volume inside bark of the main stem for living trees $>1.3 \mathrm{~m}$ tall including stump and top as well as defective and decayed wood

substantially more than the 24 million ha reported in NFI baseline data, including IUCN categories Ia, Ib, II, III, IV, V and VI (Table S5). Both estimates use NFI baseline data collected during 2000-2006, but the standard NFI baseline reports used protected area mapping data from the period, (protected areas established before 2007), whereas the new estimate reported here uses protected areas mapping data from 2016. Several protected areas were established between NFI baseline and now, increasing the area of protected forest by 5.3 million ha, according to our estimates. This is only a portion of the overall increase in Canada's terrestrial protected area (ECCC 2017).

Six percent of Canada's land area was classified as Treaty/Settlement. These lands are predominantly nonforested (89\%) because most are at high latitudes. Sixty percent of Treaty/Settlement lands are in Nunavut (Fig. 2).

Lands classified as Indian Reserve, Federal Reserve and Restricted are less than $3 \%$ of the total land area and less than $3 \%$ of Canada's forest area (Table 3 ).

Nearly half of Canada's land area was classified as Other (Fig. 2), but $74 \%$ is non-forest (Fig. 3). Even so, there are an estimated 114 million ha of forests on lands classified as Other (Table 3).

The total forest area reported in Table 3, (347.503 million ha), differs numerically from the total reported in standard NFI baseline reports ( 347.576 million ha) because the stratification used for NFI standard estimation is different from that used here. The NFI uses Terrestrial Ecozones as strata for standard estimation (Ecological Stratification Working Group 1996). Changing stratification has a small impact on the estimates. The two estimates are numerically different, but they are consistent (standard error of $0.4 \%$ ).

\section{Discussion}

Land designations were used to classify and map Canada's forests. This approach is fundamentally different from mapping forest disturbances or human footprints which involve mapping specific impacted areas. This land designation approach to mapping may be used in combination with disturbance mapping (e.g., White et al. 2017; Guindon et al. 2018) to better understand the footprint of forestry in Canada over time.
The new dataset reported here has several important shortcomings and limitations. A diversity of source datasets were used and many of these were produced at different scales or using different projections. Few had perfectly clean topology. Additional gaps and slivers were created by our overlays where there were misalignments between input layers such as shared boundaries drawn differently by different source datasets. These issues made the source GIS datasets difficult but not impossible to use. Cleaning up these issues would have involved prohibitive amounts of manual labour and many difficult choices, such as deciding which segments to retain where more than one is present representing the same feature (e.g., a boundary between a park and a forest management unit that is mapped one way on the park map and another way on the management unit map because of map scale differences). Our generalization process addressed most of these issues but it shifted some boundaries. We considered the trade-offs between retaining precise geographic boundaries from source datasets with their associated topology issues versus generalization with the associated loss of spatial precision. We elected to generalize because our focus was on producing a dataset that is sufficiently precise to be accurate at the national scale, not one that is precisely accurate at a local scale everywhere in Canada. People who are interested in doing local analyses are encouraged to use the original source data for their area of interest rather than our generalized national dataset.

The classification of water provides a good example of this issue. Areas classified as Water have a non-zero estimated forest area (Table 3) according to our analysis using NFI data. This occurs because the NFI maps land and water at 1:10,000 to $1: 20,000$ scale using stereo photo interpretation, whereas the Water class in the new dataset reported here is based on Statistics Canada's national hydrography boundary files (1:50,000 to 1:250,000 National Topographic Series map data). These map scale differences cause noteworthy discrepancies. It is also possible that some water areas have changed between the NFI baseline collection and now. Most NFI land $(98.8 \%)$ is also classified as land in our new dataset. Just over half of NFI water (55.4\%) is also classified as water in our new dataset (Table S6). The new dataset reported here could have 


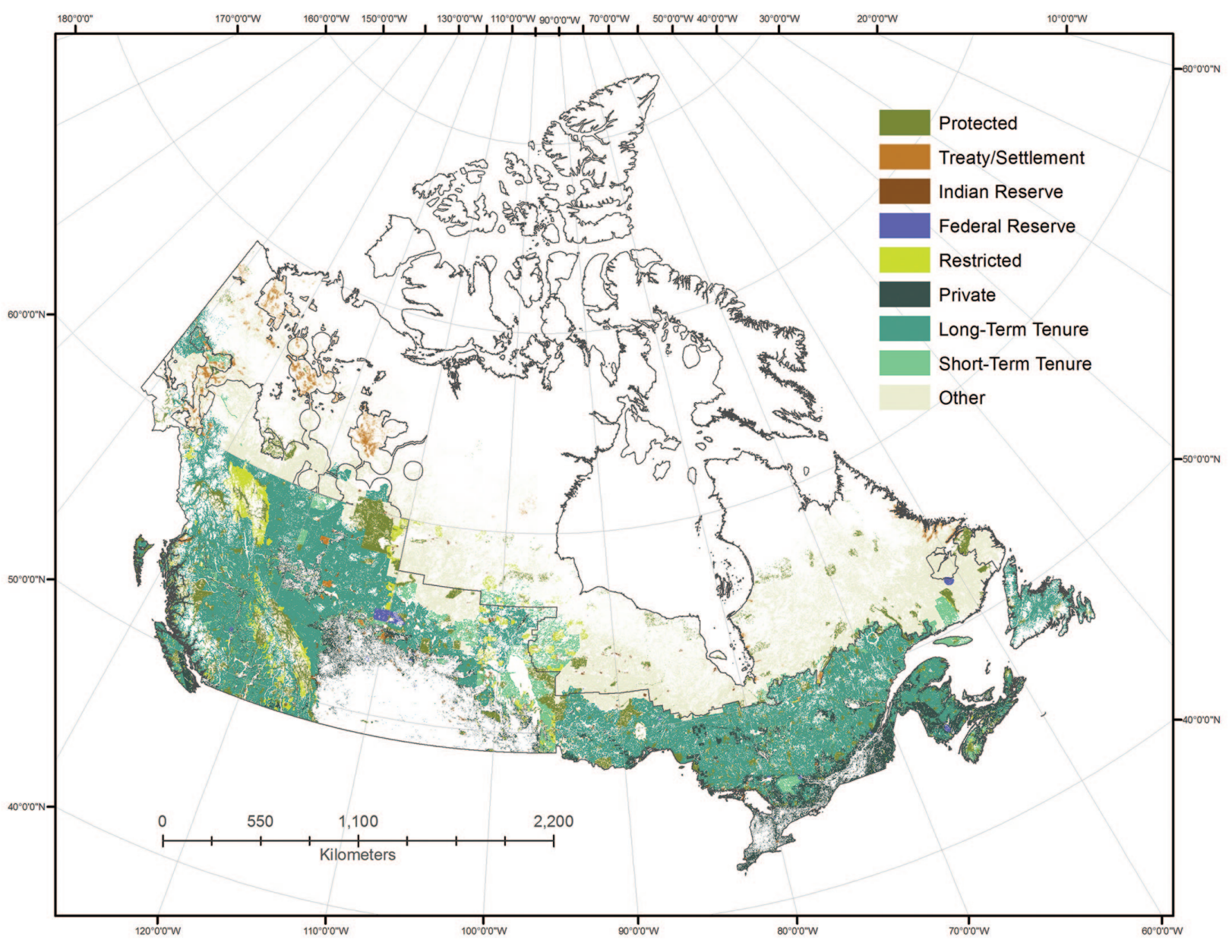

Fig. 4. Treed lands of Canada classified according to legend in Table 1, shown in relation to the boundary of the area designated as "managed forest" for national greenhouse gas inventory reporting (grey inland lines)

been created without a Water class, but some provinces include lakes in their management unit and tenure area map data so these areas were retained for consistency with the original source data. Ideally, inland water features would not be included as a class. That way, data users could apply their own water feature datasets when doing geospatial overlays and avoid discrepancies such as those shown in Table S6.

Another generalization embedded in our classification system (Table 1) is the fact that management intensity may vary considerably within some of our categories. For example, only $6 \%$ of Canada's forest is privately owned and all were included in a single Private class. This means that forests on large industrial freehold lands and those on family-owned woodlots are in the same category, even though their management may be very different. This problem was deemed acceptable for two reasons. Firstly, we wanted to limit the number of categories and $6 \%$ is a relatively small proportion of the national forest estate to be splitting into multiple categories. Secondly, it would be difficult to categorize private lands according to forest management practice because of the sheer variety. Small woodlot owners in particular may change plans when circumstances in their lives change or when land is passed from one generation to the next. The variety issue applies to the Restricted class as well. A wide variety of reasons for restriction are encompassed in the Restricted class. The types of activities and implications for forestry within lands classified as Restricted are diverse. Sub-classification would be required to dissect these, but we sought to create a simple legend with a small number of classes. Data users having special interest in the Restricted areas are encouraged to sub-classify to suit their needs using original source data, which provide more information on the reasons for restriction.

One problem with our classification is that categories are not always mutually exclusive. We tackled this using a binary decision tree approach (Fig. 1), so that each land unit is assigned to one and only one category. For example, we classified Protected areas before classifying Treaty/Settlement lands, so Protected areas on Treaty/Settlement lands are classified as Protected on our map. The actual area of Treaty/Settlement lands is therefore greater than the area classified as Treaty/Settlement on our map.

An important characteristic of the map is its vintage. The dataset is current as of June 2017. The best available information as of June 2017 was used to develop the dataset. Land designation in Canada is relatively stable but changes do 
occur. For example, in May of 2018, 1.36 million ha of new protected lands were established with the creation of a network of parks and protected areas in north-eastern Alberta. This included new and expanded Wildland Provincial Parks: Kazan, Richardson, Dillon River, Birch River and Birch Mountains. This represents a significant increase in Protected areas, even at the national scale. This highlights the challenge to create timely data products and refresh data products on some update cycle in order to remain relevant.

Forest age-class distributions were analyzed in each class using NFI baseline data (Table S3). There was very little Private forest older than 100 years and very little Protected forests younger than 40 years. Forests older than 200 years were found mostly in areas with Long-Term Tenure and in Protected areas.

Estimated per ha growing stock differences between classes (Table 3) must be interpreted with caution because these are not necessarily a reflection of management differences. Estimates for the smaller categories may be heavily influenced by local factors because of how they are geographically distributed. Most Federal Reserve lands, for example, are located in one place: Cold Lake Air Weapons Range (AWR). Available forest inventory data for the AWR are not as detailed as data for surrounding areas. Smaller categories notwithstanding, the highest per ha growing stocks are in forests with Long-Term Tenure and in Protected forests. The smallest per ha growing stocks are in forests on lands classified as Other, which makes sense given the geographic distribution of these lands. Nearly half of forest growing stock in Canada (46\%) is in forests with Long-Term Tenure.

The area available for timber supply cannot be calculated using the new map dataset reported here. Not all forests located on lands classified as Long-Term Tenure or ShortTerm Tenure (Table 3) are available for timber supply. Government regulations establish reserve areas within forest management units where harvesting is not permitted. In British Columbia, for example, forests in Timber Supply Areas and Tree Farm Licence areas are classified as THLB (timber harvesting land-base) and non-THLB. The nonTHLB includes parks and protected areas but it also includes riparian buffer zones and other areas where harvesting is not permitted. The scale of these reserve areas makes it impractical to represent them all in a national map. Strategic-level forest resource inventories map some of these areas; the remainder are handled during operations. The individual units of land involved are typically small, but the sum of these areas can be quite substantial. There are 55 million ha of forest in B.C., most of which are on provincial Crown land, but only 22 million ha of THLB (BCMoFML 2010).

Caution must be exercised when comparing summary statistics reported here with those published elsewhere. Similar terminology may be used to refer to very different things. In Ontario, for example, the total managed Crown forest land area is 43 million ha, whereas the managed Crown forest area available for timber production is 27.8 million ha (OMNR 2016). A portion of the 15 million ha difference consists of reserved forest areas, such as those discussed above in B.C., but the 43 million ha total also includes non-forested areas such as lakes, non-treed wetlands and rock outcrops. How does one compare such statistics to those we produced using our map? Forest land area statistics reported by different sources are not always comparable. Sometimes gross areas are reported and other times net areas are reported.

The new map and forest area estimates presented here differ from those used by Canada for greenhouse gas (GHG) inventory reporting. The United Nations Framework Convention on Climate Change (UNFCCC) obliges countries, including Canada, to report GHG emissions and removals from land use, land-use change and forestry. Many forest emissions and removals, however, are associated with natural processes, not human activities. The UNFCCC's GHG accounting rules require countries to delineate a "managed forest" 1 area so that forest lands not under the direct influence of human activities ("unmanaged forests") can be excluded from the reporting (Ogle et al. 2018). In many countries, the entire forest is classified as "managed forest" for GHG inventory purposes. This is not the case in Canada. Canadian provincial, territorial and federal government representatives developed a national boundary (Fig. 4) within which lands that meet the definition of forest are considered to be managed forest for GHG inventory purposes (ECCC 2016). This managed forest boundary includes areas where forest industry operates, but also parks and protected areas, buffer zones around forest communities and transportation corridors where people access the forest to extract resources such as fuel wood, and fire response zones. The UNFCCC rules do not allow removal of lands from managed forest designation. Forests managed at any time since 1990 must be considered part of the managed forest for GHG inventory purposes, even if they are no longer managed. The managed forest boundary does not provide a representation of where forest management currently occurs in Canada. That was not its purpose. Its purpose was to serve as a proxy for factoring naturally occurring forest GHG emissions and removals out of national GHG inventory reporting (Ogle et al. 2018).

Most forests (approximated by tree cover in Fig. 4) beyond the UNFCCC managed forest boundary were classified as Other in our dataset, but there are also many areas inside the UNFCCC managed forest boundary that were classified as Other. Most of the areas included in GHG inventory reporting that we classified as Other are areas that were included in the GHG inventory reporting boundary because they were inside intensive fire management zones at the time, or near communities or transportation corridors. Fire management zones were not considered in our classification because the frequency of extreme wild fire events has increased and agencies now focus much of their energies on protecting public safety and infrastructure. With a measured response approach, not all fires will be actioned in the same way. Depending on various factors, some fires may not be actioned at all.

Another cause of differences between the forested areas reported here, compared to those reported in Canada's GHG inventory, is the source of forest inventory data. Canada's National Forest Carbon Monitoring, Accounting and Reporting System (NFCMARS) does not directly use NFI inputs; instead, it uses the forest resource inventories that

${ }^{1} 2006$ IPCC Guidelines for National Greenhouse Gas Inventories say that "Managed land is land where human interventions and practices have been applied to perform production, ecological or social functions" (Section 3.2, Volume 4, available at IPCC website: https://www.ipcc-nggip.iges.or.jp/public/2006gl/) 
provinces and territories compile for timber supply analysis (Stinson et al. 2011). The current managed forest area reported by NFCMARS is 226 million ha (ECCC 2018). The forest area in all classes, excluding Other on our map, is 234 million ha, according to NFI baseline data (Table 3 and Fig. 4). This area differs from the NFCMARS managed forest area because of differences in definitions, standards, methods and geographic extent.

\section{Conclusions}

The geographic extent of forest management in Canada cannot be fully understood using a binary managed/unmanaged classification. Ownership, tenure and management objectives vary considerably across Canada's forests.

The geographic extent of commercial forest management in Canada is determined by biophysical, economic, and social factors. Biophysical factors such as soil fertility and climate limit tree growth in many areas. Economic factors, such as distance to markets, limit society's interest in harvesting timber in places where expected revenues do not exceed the costs of getting products to market. Social factors such as ownership and governance ultimately decide where and how forests may be managed. In Canada, where most forests are on Crown land, 'social licence' can be the ultimate deciding factor (Bunnell 2013).

The map described in this paper can be used as a tool for understanding the geography of forest management in a way that earlier binary forest classification maps could not. The map dataset is not perfect, however, and it has already become out-dated in some areas. Collaborating government agencies plan to update the dataset periodically as needed. The authors are open to receiving advice from experts concerning refinement priorities for future versions.

\section{Data Availability}

The dataset may be freely accessed through the National Forest Information System (nfis.org) or the Government of Canada's Open Data Portal (https://open.canada.ca/en/ open-maps). The data may be downloaded as an ESRI geodatabase from either of these sites. The data are also available as an Open GIS Consortium (OGC) Web Mapping Service and as an OGC Web Feature Service.

The data should not be treated as official maps of forest tenure areas, protected areas, forest ownership or First Nation, Metis or Inuit lands. The data were derived from map data available to us for the purposes of mapping forest management areas in Canada. Data users engaged in other types of assessments are encouraged to obtain original data from official sources.

The forest management areas dataset will be updated periodically as the need arises. The present version is current to June 2017. Changes since then are not reflected in the data.

\section{Acknowledgements}

This project was initiated and supported by the Canadian Council of Forest Ministers. The National Forest Information System (nfis.org) project office provided invaluable support making the map data and services freely available online. Jeannette Strand designed the cartography for Fig. 2 and Fig. 4 as well as the WMS. Paul Boudewyn and Frank Eichel completed the NFI estimation reported in this paper with support from Xilong (Alex) Song and other members of the NFI project office team. We thank our reviewers for the comments they provided; these significantly improved the manuscript.

\section{References}

Apsey, M., D. Laishley, V. Nordin and G. Paillé. 2000. The perpetual forest: Using lessons from the past to sustain Canada's forests in the future. For. Chron. 76(1): 29-53

BCMoFML 2010. (British Columbia Ministry of Forests, Mines and Lands). The State of British Columbia's Forests. Third Edition. Forest Practices and Investment Branch, Victoria, B.C.

Beaudoin, A., P.Y. Bernier, L. Guindon, P. Villemaire, X.J. Guo, G. Stinson, T. Bergeron, S., Magnussen and R.J. Hall. 2014. Mapping attributes of Canada's forests at moderate resolution through kNN and MODIS imagery. Can. J. For. Res. 44: 521-532. Doi: 10.1130/cjfr-2013-0401

Bunnell, F. 2013. Social licence in British Columbia: Some implications for energy development. J. Ecosystems Manage. 14(1): 1-16.

CCEA 2008. (Canadian Council on Ecological Areas). Canadian Guidebook: For the application of IUCN Protected Area Categories 2008. CCEA Occasional Paper No. 18. Canadian Council on Ecological Areas, CCEA Secretariat, Ottawa, Ontario, Canada. 66 pp. CCEA 2016. (Canadian Council on Ecological Areas). CARTS: the Conservation Areas Reporting and Tracking System geodatabase. Available at: http://www.ccea.org/carts/ [accessed June 2017]

CCFM 2007. (Canadian Council of Forest Ministers). Criteria and Indicators of Sustainable Forest Management in Canada: Key Trends and Conditions 2005. Canadian Council of Forest Ministers, Ottawa.

ECCC 2017. (Environment and Climate Change Canada). Canadian Environmental Sustainability Indicators: Canada's protected areas. Available at: https://www.ec.gc.ca/indicateurs-indicators/ default.asp?lang=en \&n=478A1D3D-1\&wbdisable $=$ true $[$ accessed August 2018].

ECCC 2018. (Environment and Climate Change Canada). National Inventory Report 1990-2016.: Greenhouse Gas Sources and Sinks in Canada. Canada's Submission to the United Nations Framework Convention on Climate Change. Part 1 (Chapter 6). Available at http://publications.gc.ca/collections/collection_2018/eccc/En8142016-1-eng.pdf (Accessed June 2019)

Ecological Stratification Working Group. 1996. A National Ecological Framework for Canada. Agriculture and Agri-Foods Canada, Research Branch, Centre for Land and Biological Resources Research and Environment Canada, State of the Environment Directorate, Ottawa. 125 pp. and a national map at 1:7 500000 scale. FAO 2012. (Food and Agriculture Organization of the United Nations). FRA 2015 Terms and Definitions. Forest Resources Assessment Working Paper 180. Food and Agriculture Organization of the United Nations, Rome. Available at: http://www.fao.org/ documents/card/en/c/5d917495-a5de-5b0c-851a-c0010269d79d/ [Accessed November 2016]

Gillis M.D. and D.G. Leckie. 1993. Forest inventory mapping procedures across Canada. Forestry Canada, Petawawa National Forestry Institute, Chalk River. Information Report PI-X-114

Government of Canada 2016. Directory of Federal Real Property. Version 20.5. Treasury Board of Canada Secretariat. Available at https://www.tbs-sct.gc.ca/dfrp-rbif/introduction-eng.aspx [Accessed April 2017]

Guindon, L., P.Y. Bernier, S. Gauthier, G. Stinson, P. Villemaire and A. Beaudoin. 2018. Missing forest cover gains explained. Ecosphere 9: e02094. https://doi.org/10.1002/ecs2.2094

Montreal Process. 2015. The Montreal Process Criteria and Indicators for the Conservation and Sustainable Management of Temperate and Boreal Forests. Fifth Edition. http://www.montreal process.org/ [Accessed August 2018]

NFD 2019. (National Forestry Database). Table 5.1 Net merchantable volume of roundwood harvested by jurisdiction, tenure, 
category and species group. Available at: nfdp.ccfm.org [accessed March 2019]

NFI 2004. (National Forest Inventory). Canada's National Forest Inventory Estimation Procedures. Version 1.13. Available at: https://nfi.nfis.org/resources/estimation/Estimation_procedures_ v1.13.pdf [accessed October 2018]

NRCan 2016. (Natural Resources Canada). Geobase - Aboriginal Lands. Natural Resources Canada. Available at: https:// open.canada.ca/data/en/dataset/522b07b9-78e2-4819-b736ad9208eb1067 [accessed April 2017]

NRCan 2017. (Natural Resources Canada). The State of Canada's Forests: Annual Report 2017. Natural Resources Canada. Available at: http://cfs.nrcan.gc.ca/pubwarehouse/pdfs/38871.pdf [accessed October 2018]

NRCan 2018. (Natural Resources Canada). The State of Canada's Forests: Annual Report 2018. Natural Resources Canada. Available at: http://www.nrcan.gc.ca/forests/report/16496 [accessed October 2018]

Ogle S.M., G. Domke, W.A. Kurz, M.T. Rocha, T. Huffman, A. Swan, J.E. Smith, C. Woodall and T. Krug. 2018. Delineating managed land for reporting national greenhouse gas emissions and removals to the United Nations framework convention on climate change. Carbon Balance and Management 13:9. https://doi.org/ 10.1186/s13021-018-0095-3

OMNR 2016. (Ontario Ministry of Natural Resources). State of Ontario's Natural Resources - Forests 2016. Queen's Printer for Ontario. Sault Ste. Marie, Ontario.

Potapov P., M.C. Hansen, L. Laestadius, S. Turubanova, A. Yaroshenko, C. Thies, W. Smith, I. Zhuravleva, A. Komarova, S. Minnemeyer and E. Esipova. 2017. The last frontiers of wilderness: Tracking loss of intact forest landscapes from 2000 to 2013. Science Advances 3(1), e1600821. https://doi.org/10.1126/sciadv.1600821
Statistics Canada 2011. 2011 Census - Boundary files. Lakes and rivers (polygons). http://www12.statcan.gc.ca/census-recensement/2011/geo/bound-limit/bound-limit-2011-eng.cfm [Accessed May 2018]

Stinson G., S. Magnussen, P. Boudewyn, F. Eichel, G. Russo, M. Cranny and X. Song. 2016. Chapter 12: Canada. In: Vidal C., I. Alberdi, L. Hernandez and J. Redmond (Eds). National Forest Inventories - Assessment of Wood Availability and Use. Springer.

Stinson G., W.A. Kurz, C.E. Smyth, E.T. Neilson, C.C. Dymond, J.M Metsaranta, C. Boisvenue, G.J. Rampley, Q. Li, T.M. White and D. Blain. 2011. An inventory-based analysis of Canada's managed forest carbon dynamics, 1990 to 2008. Glob. Change Bio. 17: 2227-2244. https://doi.org/10.1111/j.1365-2486.2010.02369.x

Venier, L.A., R. Walton, I.D. Thompson, A. Arsenault and B.D. Titus. 2018. A review of the intact forest landscape concept in the Canadian boreal forest: Its history, value and measurement. Environ. Rev. 26: 369-377. https://doi.org/10.1139/er-2018-0041

Watson, J.E., T. Evans, O. Venter, B. Williams, A. Tulloch, C. Stewart, I. Thompson, J.C. Ray, K. Murray and A. Salazar. 2018. The exceptional value of intact forest ecosystems. Nature Ecol. Evol. 1. https://doi.org/10.1038/s41559-018-0490-x

White, J.C., M.A. Wulder, T. Hermosilla, N.C. Coops and G. Hobart. 2017. A nationwide annual characterization of 25 years of forest disturbance and recovery for Canada using Landsat time series. Remote Sens. Environ. 194: 303-321. https://doi.org/ 10.1016/j.rse.2017.03.035

Wulder M.A., J.C. White, M. Cranny, R.J. Hall, J.E. Luther, A. Beaudoin, D.G. Goodenough and J.A. Dechka. 2008. Monitoring Canada's forests. Part 1: Completion of the EOSD land cover product. Can. J. Remote Sens. 34(6):549-562. 